\title{
Study of Insertion of Olefins and/or Carbon Monoxide into Phosphine-Imine Palladium Methyl Complexes
}

\author{
K. Rajender Reddy, K. Surekha, Gene-Hsiang Lee, Shie-Ming Peng, \\ J wu-Ting Chen, and Shiuh-Tzung Liu* \\ Department of Chemistry, National Taiwan University, Taipe, Taiwan 106, Republic of China
}

Received October 16, 2000

\begin{abstract}
Palladium methyl complexes with a phosphine-imine $(\mathbf{P} \sim \mathbf{N})$ bidentateligand, $[\mathrm{Pd}(\mathbf{P} \sim \mathbf{N})$ $\mathrm{MeCl}]$ (1), $\left[\mathrm{Pd}(\mathbf{P} \sim \mathbf{N}) \mathrm{Me}\left(\mathrm{CH}_{3} \mathrm{CN}\right)\right]\left(\mathrm{BF}_{4}\right)(\mathbf{2})$, and $\left[\mathrm{Pd}(\mathbf{P} \sim \mathbf{N}) \mathrm{Me}\left(\mathrm{PPh}_{3}\right)\right]\left(\mathrm{BF}_{4}\right)(\mathbf{3})$, are treated with $\mathrm{CO}$ to result in the corresponding Pd-acyl complexes 4-6. NMR studies indicate the formation of a sole isomer with the acyl group cis to the phosphine donor. The neutral complex 4 and the triphenylphosphine-substituted complex $\mathbf{6}$ cannot servefor the insertion of ethylene. However, the acetonitrile complex $\mathbf{5}$ appears to be active in the insertion reaction with various alkenes as well as ethylene/CO (E-CO) co-oligomerization, resulting in the products 7-14 and 16, which have been isolated and characterized by spectroscopic methods. X-ray structures of $\mathbf{1}, \mathbf{2}, \mathbf{3}, \mathbf{4}, \mathbf{7}, \mathbf{1 0}, \mathbf{1 1}$, and $\mathbf{1 3}$ are revealed.
\end{abstract}

\section{Introduction}

Insertion of small unsaturated molecules into the metal-carbon bond is an important step for the metalcatalyzed reactions of $\mathrm{C}-\mathrm{C}$ bond formation. ${ }^{1}$ Among them, the alternating insertion of carbon monoxide and ol efins into metal-carbon bonds leading to the formation of polyketones by various palladium complexes has received considerable interest. ${ }^{2}$ It is known that the coordinating ability of the ligand and its steric environments generally control the efficiency of the catalyst. In this regard, palladium-based catalysts with symmetrical bidentate phosphorus $[\mathrm{P}-\mathrm{P}]^{3}$ or nitrogen $[\mathrm{N}-\mathrm{N}]^{4}$ donor atoms are found to be very effective. A number of stoichiometric and theoretical studies have provided valuable information on mechanistic aspects of migra-

* E-mail: stliu@ccms.ntu.edu.tw.

(1) Collman, J. P.; Hegedus, L. S.; Norton, J. R.; Finke, R. G. Principles and Applications of Organotransition Metal Chemistry; University Science Books: Mill Valley, CA, 1987. (b) Cornils, B.; Herrmann, W. A. Applied Homogeneous Catalysis with Organometallic Compounds; VCH: Weinheim, Germany, 1996; Vol. 1.

(2) F or recent reviews see: (a) Ittel, S. D.; J ohnson, L. K.; Brookhart, M. Chem. Rev. 2000, 100, 1169. (b) Britovsek, G. J . P.; Gibson, V. C.; Wass, D. Angew. Chem., Int. Ed. 2000, 38, 428. (c) Drent, E.; Budzelaar, P. H. M. Chem. Rev. 1996, 96, 663. (d) Cavell, K. J . Coord. Chem. Rev. 1996, 155, 209. (e) Sen, A. Acc. Chem. Res. 1993, 26, 303.

(3) For Pd-polyketone catalysts with symmetrical $\mathrm{P}-\mathrm{P}$ ligands see: (a) Schwarz, J .; Herdtweck, E.; Herrmann, H.; Gardiner, M. G. Organometallics 2000, 19, 3154. (b) Verspui, G.; Schanssema, F. Sheldon, R. A. Angew. Chem., Int. Ed. 2000, 39, 804. (c) Bianchini, C.; Lee, H. M.; Meli, A.; Oberhauser, W.; Vizza, F .; Bruggeller, P.; Haid, R.; Langes, C. Chem. Commun. 2000, 777. (d) Doherty, S.; Eastham, G. R.; Tooze, R. P.; Scanlan, T. H.; Williams, D.; Elsegood, M. R. J .; Clegg, W. Organometallics 1999, 18, 3558. (e) Safir, A. L.; N ovak, B. M. J . Am. Chem. Soc. 1998, 120, 643. (f) Kacker, S.; J iang, Z.; Sen, A. Macromolecules 1996, 29, 5852. (g) Abu-Surrah, A. S.; Wursche, R.; Rieger, B.; Eckert, G.; Pechhold, W. Macromol ecules 1996, 29, 4806. (h) J iang, Z.; Sen, A. J . Am. Chem. Soc. 1995, 117, 4455. (i) Drent, E. van Breokhoven, J. A. M.; Doyle, M. J . J . Organomet. Chem. 1991, 417, 235.

(4) F or Pd-polyketone catalysts with symmetrical $\mathrm{N}-\mathrm{N}$ ligands see: (a) Milani, B.; Alessio, G.; Zangrando, E.; Randaccio, L.; Consiglio, G. J . Chem. Soc., Dalton Trans. 1996, 1021. (b) J iang, Z.; Adams, S E.; Sen, A. Macromolecules 1994, 27, 2694. (c) Sen, A.; J iang, Z. Macromolecules 1993, 26, 911. (d) Brookhart, M.; Rix, F. C.; DeSimone, J. M.; Barborak, J. C. J . Am. Chem. Soc. 1992, 114, 5894. tory insertion of $\mathrm{CO}$ and ol efins into Pd-al kyl and Pdacyl bonds, respectively. ${ }^{5-7}$

Recently, interest in searching for new catalysts with unsymmetrical bidentate ligands has been increasing, ${ }^{8-11}$ particularly with $\mathrm{P}-\mathrm{N}$ ligands. ${ }^{12,13}$ Although the palladium complexes with phosphino-oxazolines ligands in

(5) For $\mathrm{CO}$ and/or olefin insertion and mechanistic studies of Pdcomplexes with P-P ligands see: (a) Shultz, C. S.; Ledford, J DeSimone, J. M.; Brookhart, M. J. Am. Chem. Soc. 2000, 122, 6351. (b) Barlow, G. K.; Boyle, J . D.; Cooley, N. A.; Ghaffar, T.; Wass, D. F. Organometallics 2000, 19, 1470. (c) Parlevliet, F. J : Zuideveld, M. A Kiener, C.; Kooijman, H.; Spek, A. L.; Kamer, P. C.; van Leeuwen, P. W. N. M. Organometallics 1999, 18, 3394. (d) Zuideveld, M. A.; Kamer, P. C. J ; van Leeuwen, P. W. N. M.; Klusener, P. A. A.; Stil, H. A.; Roobeek, C. F. J . Am. Chem. Soc. 1998, 120, 7977. (e) Kacker, S.; Sen, A. J . Am. Chem. Soc. 1997, 119, 10028. (f) Toth, I.; Elsevier, C. J . J . Am. Chem. Soc. 1993, 115, 10388. (g) Batistini, A.; Consiglio, G. Organometallics 1992, 11, 1766. (h) Dekker: G. P. C. M.; Elsevier: C. J .; Vrieze, K.; van Leeuwen, P. W. N. M. Organometallics 1992, 11, 1598. (i) Dekker, G. P. C. M.; Elsevier: C. J .; Vrieze, K.; van Leeuwen, P. W. N. M.; Roobeek, C. F. J . Organomet. Chem. 1992, 430, 357. (j) Ozawa, F.; Hayashi, T.; Koide, H.; Yamamoto, A. J . Chem. Soc., Chem. Commun. 1991, 1469.

(6) For $\mathrm{CO}$ and/or ol efin insertion and mechanistic studies of Pdcomplexes with $\mathrm{N}-\mathrm{N}$ ligands see: (a) Carfagna, C.; Formica, M.; Gatti, G.; Musco, A.; Pierleoni, A.J . Chem. Soc., Chem. Commun. 1998, 1113. (b) Groen, J . H.; Delis, J. G. P.; van Leeuwen, P. W. N. M.; Vrieze, K. Organometallics 1997, 16, 68. (c) Delis, J . G. P.; van Leeuwen, P. W. N. M.; Vrieze, K.; Veldman, N.; Spek, A. L.; Fraanje, J :; Goubitz, K. I Organomet. Chem. 1996, 514, 125. (d) Rix, F. C.; Brookhart, M.; White, P. S. J . Am. Chem. Soc. 1996, 118, 4746. (e) Markies, B. A.; Kruis, D.; Rietveld, M. H. P.; Verkerk, K. A. N.; Boersma, J :; Kooijman, H.; Lakin, M. T.; Spek, A. L.; van Koten, G. J. Am. Chem. Soc. 1995, 117, 5263. (f) Rix, F. C.; Brookhart, M. J . Am. Chem. Soc. 1995, 117, 1137. (g) van Asselt, R.; Gielens, E. E. C. G.; Rülke, R. E.; Vrieze, K.; Elsevier, C. J . J . Am. Chem. Soc. 1994, 116, 977. (h) van Asselt, R.; Gielens, E E. C. G.; Rülke, R. E.; Elsevier, C. J . J . Chem. Soc., Chem. Commun. 1993, 1203.

(7) For theoretical studies on CO and olefin copolymers see: (a) Svensson, M.; Matsubara, T.; Morokuma, K. Organometallics 1996, 15, 5568. (b) Margl, P.; Ziegler, T. Organometallics 1996, 15, 5519.

(8) For CO and/or ol efin insertion and catalytic studies with unsymmetrical ( $\left.\mathrm{P}-\mathrm{P}^{*}\right) \mathrm{Pd}$-complexes see: (a) Gambs, C.; Chaloupka, S.; Consiglio, G.; Togni, A. Angew. Chem., Int. Ed. 2000, 39, 2486. (b) Nozaki, K.; Hiyama, T.; Kacker, S.; Horvath, I. Organometallics 2000, 19, 2031. (c) Nozaki, K.; Sato, N.; Tonomura, Y.; Yasutomi, M.; Takaya, H.: Hiyama, T.; Matsubara, T.; Koga, N.J . Am. Chem. Soc. 1997, 119 12799. (d) Keim, W.; Mass, H. J . Organomet. Chem. 1996, 514, 271. (e) van Leeuwen, P. W. N. M.; Roobeek, C. F.; van der Heijden, H. J . Am. Chem. Soc. 1994, 116, 12117. 
asymmetric catalysis have been reported, ${ }^{14}$ ligands with phosphorus and $\pi$-accepting imine nitrogen donors in palladium-catalyzed reactions show very promising activity for homo- and copolymerization. ${ }^{13}$ Unlike the symmetrical counterparts, the soft and hard nature of phosphorus and nitrogen, combined with their trans effecting nature, are expected to influence the binding properties of the substrates as well as migratory insertion with keen discerning ability. I solation and characterization of the insertion intermediates with $\mathrm{P}-\mathrm{N}$ ligands can contribute valuable information on the reactivity of these catalysts. ${ }^{13}$ Some prel iminary results concerning the insertions of $\mathrm{CO}$ with various functionalized alkenes and alkynes in cationic palladium complexes $[\mathrm{Pd}(\mathbf{P} \sim \mathbf{N})(\mathrm{Me}) \mathrm{L}]^{+}$from our laboratory were reported recently. ${ }^{15}$ Continuing this trend, we report the synthesis and detailed structural characterization of both neutral and cationic palladium complexes and their reactivity toward $\mathrm{CO}$ and various olefins.

\section{Results}

Preparation of Ligand and the $[\mathrm{Pd}(\mathbf{P} \sim \mathbf{N}) \mathrm{MeCI}]]$ Complex. The phosphine-imine ligand was prepared by simple condensation of 2-(diphenylphosphino)aniline ${ }^{16}$ with excess benzaldehyde and characterized by spectroscopic methods. Substitution reaction of $\mathrm{Pd}$ (COD) $\mathrm{MeCl}^{17}$ with the $\mathbf{P} \sim \mathbf{N}$ ligand in a THF solution provided the neutral methyl palladium complex [Pd$(\mathbf{P} \sim \mathbf{N}) \mathrm{MeCl}$ (1) in excellent yield. Recrystallization

(9) For $\mathrm{CO}$ and/or ol efin insertion and catalytic studies with unsymmetrical ( $\left.\mathrm{N}-\mathrm{N}^{*}\right) \mathrm{Pd}$-complexes see: (a) Meneghetti, S. P.; Lutz, P. J ; Kress, J . Organometallics 1999, 18, 2734. (b) Groen, J . H.; Vlaar, M.; van Leeuwen, P. W. N. M.; Vrieze, K.; Kooijman, H.; Spek, A. L. J. Organomet. Chem. 1998, 551, 67. (c) Rülke, R. E.; Delis, J . G. P.; Groot, A. M.; Elsevier: C. J .; van Leeuwen, P. W. N. M.; Vrieze, K.; Goubitz, K.; Schenk, H. J. Organomet. Chem. 1996, 508, 109. (d) Delis, J. G. P.; Rep, M.; Rulke, R. E.; van Leeuwen, P. W. N. M.; Vrieze, K.; Fraanje, J .; Goubitz, K. Inorg. Chim. Acta 1996, 250, 87.

(10) For CO and/or olefin insertion and catalytic studies with unsymmetrical ( $\mathrm{N}-\mathrm{O}) \mathrm{Pd}$-complexes see: (a) Green, M. J .; Britovsek, G. J. P.; Cavell, K. J .; Gerhards, F.; Yates, B. F.; Frankcombe, K.; Skelton, B. W.; White, A. H. J . Chem Soc., Dalton Trans. 1998, 1137. (b) Gree, M. J .; Bristovsek. G. J . P.; Cavell, K.J .; Skelton, B. W.; White, A. H. J . Chem. Soc., Chem. Commun. 1996, 1563. (c) Frankcombe, K.; Cavell, K.; Yates, B. J . Chem. Soc., Chem. Commun. 1996, 781. (d) Hoare, J . L.; Cavell, K. J .; Hecker, R.; Skelton, B. W.; White, A. H. J . Chem Soc., Dalton Trans. 1996, 2197.

(11) For $\mathrm{CO}$ and/or olefin insertion and catalytic studies with unsymmetrical ( $\mathrm{P}-\mathrm{O}) \mathrm{Pd}$-complexes see: (a) Braunstein, $\mathrm{P}$.; Frison, $\mathrm{C}$.; Morise, X. Angew. Chem., Int. Ed. 2000, 39, 2867, and references therein. (b) Bristovsek, G. J. P.; Keim, W.; Mecking, S.; Sainz, D.; Wagner, T. J . Chem. Soc., Chem. Commun. 1993, 1632.

(12) For catalytic studies with (P-N)Pd-complexes see: (a) Braunstein, P.; Fryzuk, M. D.; Le Dall, M.; Naud, F.; Rettig, S. J .; Speiser, F. J . Chem Soc., Dalton Trans. 2000, 1067. (b) van den Beuken, E. K.; Smeets, W. J . J .; Spek, A. L.; Feringa, B. L. Chem. Commun. 1998, 223. (c) Aeby, A.; Gsponer, A.; Consiglio, G. J . Am. Chem. Soc. 1998, 120, 11000. (d) Aeby, A.; Bangerter, F.; Consiglio, G. Helv. Chim. Acta 1998, 81, 764. (e) Aeby, A.; Consiglio, G. Helv. Chim. Acta 1998, 81, 35. (f) Sperrle, M.; Consiglio, G. Helv. Chim. Acta 1996, 79, 1387.

(13) For insertion studies with (P-N)Pd-complexes see: (a) Brinkmann, P. H. P.; Luinstra, G. A. J . Organomet. Chem. 1999, 572, 193 (b) Aeby, A.; Consiglio, G. J . Chem. Soc., Dalton Trans. 1999, 655. (c) Luinstra, G. A.; Brinkmann, P. H. P. Organometallics 1998, 17, 5160. (d) Dekker, G. P. C. M.; Buijs, A.; Elsevier, C. J .; Vrieze, K.; van Leeuwen, P. W. N. M.; Smeets, W. J .J .; Spek, A. L.; Wang, Y. F.; Stam, C. H. Organometallics 1992, 11, 1937.

(14) Helmchen, G.; Pfaltz, A. Acc. Chem. Res. 2000, 33, 336, and references therein.

(15) Reddy, K. R.; Chen, C.-L.; Liu, Y.-H .; Peng, S.-M.; Chen, J .-T.; Liu, S.-T. Organometallics 1999, 18, 2574.

(16) Cooper, M. K.; Downes, J. M.; Duckworth, P. A. Inorg. Synth. 1989, 25, 129.

(17) Rulke, R. E.; Ernsting, J . M.; Spek, A. L.; Elsevier: C. J .; van Leeuwen, P. W. N. M.; Vrieze, K. Inorg. Chem. 1993, 32, 5769.
Table 1. Selected IR and NMR Data of Free Ligand and Its Palladium Complexesa,b

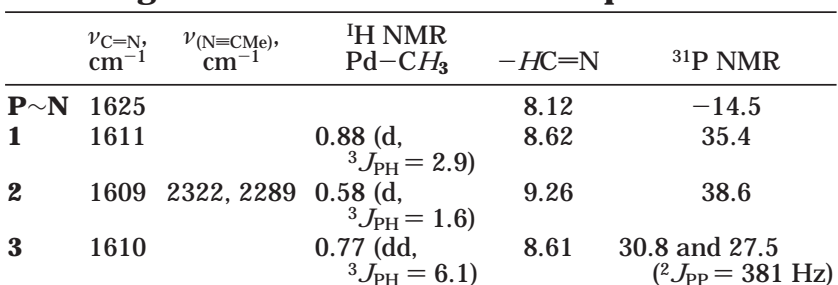

a In $\mathrm{KBr}$. bl $\mathrm{CDCl}_{3}, \mathrm{ppm}$, J in $\mathrm{Hz}$.

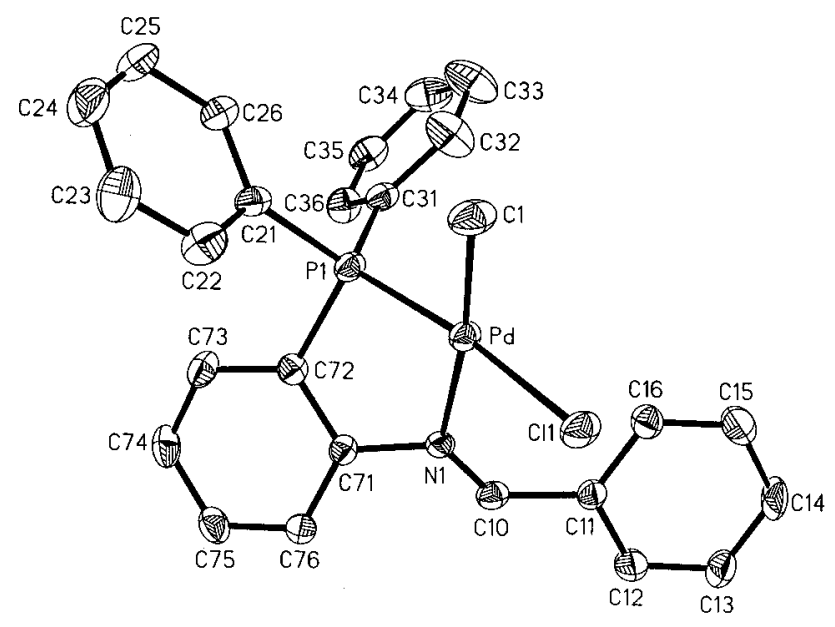

Figure 1. ORTEP plot of complex 1.

from dichloromethane and hexane gave the analytically pure product. Spectroscopic analysis confirms the structure of the complex (Table 1). A downfield shift of ca. $50 \mathrm{ppm}$ with respect to the free ligand reflects the coordination of the phosphine to the palladium metal. ${ }^{18,19}$ Appearance of a single peak in the ${ }^{31 P}$ NMR for the complex suggests the formation of a single isomer. The ster eochemistry of the methyl group cis to the phosphorus was established from its ${ }^{1} \mathrm{H}$ NMR spectra, where the methyl group bound to the palladium appears as a doublet with a coupling constant $\mathrm{J}_{\mathrm{P}-\mathrm{H}} \approx 3.0 \mathrm{~Hz}$, which is in the typical range for the cis-[ $\mathrm{PdMeCl}(\mathrm{P}-\mathrm{N})]$ complexes. ${ }^{12 a, 20}$

Further confirmation of cis-geometry for $\mathbf{1}$ is obtained from the X-ray structural analysis. The ORTEP diagram for 1, as shown in the Figure 1, indicates the square planar geometry around the palladium metal center with the phosphine and methyl groups being cis to each other. Selected bond lengths and angles are listed in the Table 2, which are in agreement with the reported $[\mathrm{Pd}(\mathrm{P}-\mathrm{N}) \mathrm{RX}]$ complexes. ${ }^{12 \mathrm{~b}, 20}$

Preparation of the Cationic $[\mathbf{P d}(\mathbf{P} \sim \mathbf{N}) \mathbf{M e}(\mathbf{L})]^{+}\{\mathbf{L}$ $=\mathbf{C H}_{3} \mathbf{C N}$ or $\left.\mathbf{P P h}_{3}\right\}$ Complexes. The cationic complex $\mathbf{2}$ is prepared by the treatment of $\mathbf{1}$ with $\mathrm{AgBF}_{4}$ in a mixture of dichloromethane and acetonitrile solution (Scheme 1). After the removal of $\mathrm{AgCl}$ by filtration, the solution was evaporated to a small volume and the desired complex was precipitated upon the addition of

(18) Pelagatti, P.; Bacchi, A.; Carcelli, M.; Costa, M.; Fochi, A.; Ghidini, P.; Leporati, E.; Masi, M.; Pelizzi, C.; Pelizzi, G. J . Organomet. Chem. 1999, 583, 94.

(19) Bhattacharyya, P.; Parr, J .; Slawin, A. M. Z. J . Chem. Soc., Dalton Trans. 1998, 3609.

(20) Ankersmit, H. A.; Løken, B. H.; Kooijman, H.; Spek, A. L.; Vrieze, K.; van Koten, G. Inorg. Chim. Acta 1996, 252, 141. 
Table 2. Selected Bond Distances $(\AA)$ and Angles (deg) of Palladium Complexes

\begin{tabular}{|c|c|c|c|c|c|c|c|c|c|}
\hline & 1 & 2 & 3 & 4 & 7 & 9 & 10 & 11 & 13 \\
\hline $\begin{array}{l}\mathrm{Pd}-\mathrm{Cl} \\
\mathrm{Pd}-\mathrm{Cl}\end{array}$ & $\begin{array}{l}2.029(6) \\
2375(2)\end{array}$ & $2.045(4)$ & $2.075(7)$ & $\begin{array}{l}1.983(3) \\
23777(7)\end{array}$ & $2.022(5)$ & $2.003(9)$ & $2.026(4)$ & $2.059(3)$ & $2.034(5)$ \\
\hline $\mathrm{Pd}-\mathrm{Cl} 1$ & & & & & & & & & \\
\hline $\begin{array}{l}\mathrm{Pd}-\mathrm{N} 1 \\
\mathrm{Pd}-\mathrm{N} 2\end{array}$ & $2.224(4)$ & $\begin{array}{l}2.198(3) \\
2.112(3)\end{array}$ & $2.183(5)$ & $2.284(2)$ & $2.208(3)$ & $2.182(7)$ & $2.191(3)$ & $2.148(3)$ & $2.175(4)$ \\
\hline $\begin{array}{l}\mathrm{Pd}-\mathrm{P} 1 \\
\mathrm{Pd}-\mathrm{P} 2\end{array}$ & $2.196(2)$ & $2.2075(9)$ & $\begin{array}{l}2.312(2) \\
2.333(2)\end{array}$ & $2.2495(7)$ & $2.180(1)$ & $2.186(2)$ & $2.186(9)$ & $2.212(1)$ & $2.189(1)$ \\
\hline $\mathrm{Pd}-\mathrm{O} 1$ & & & & & $2.143(3)$ & $2.127(4)$ & $2.148(3)$ & $2.161(2)$ & $2.112(3)$ \\
\hline $\mathrm{C} 1-\mathrm{Pd}-\mathrm{Pl}$ & $91.6(2)$ & $90.38(13)$ & $92.2(2)$ & $97.48(9)$ & $92.7(2)$ & $95.4(3)$ & $93.05(13)$ & $95.89(12)$ & $94.8(2)$ \\
\hline $\mathrm{P} 1-\mathrm{Pd}-\mathrm{N} 1$ & $81.37(11)$ & $83.28(7)$ & $79.49(14)$ & $78.90(6)$ & $82.98(9)$ & $81.6(2)$ & $83.36(8)$ & $82.76(7)$ & $82.37(10)$ \\
\hline $\begin{array}{l}\mathrm{C} 1-\mathrm{Pd}-\mathrm{N} 1 \\
\mathrm{~N} 1-\mathrm{Pd}-\mathrm{Cl} 1\end{array}$ & $\begin{array}{l}172.7(2) \\
0856(1)\end{array}$ & 173.61(14) & $170.9(2)$ & 176.18(11) & $175.2(2)$ & $175.4(4)$ & 176.03(14) & 177.72(14) & $175.6(2)$ \\
\hline $\begin{array}{l}\mathrm{N} 1-\mathrm{Pd}-\mathrm{Cl} 1 \\
\mathrm{C} 1-\mathrm{Pd}-\mathrm{Cl} 1\end{array}$ & $\begin{array}{l}98.56(11) \\
88.1(2)\end{array}$ & & & $\begin{array}{l}97.85(6) \\
85.92(9)\end{array}$ & & & & & \\
\hline $\mathrm{Cl} 1-\mathrm{Pd}-\mathrm{P} 1$ & $170.96(7)$ & & & $169.78(3)$ & & & & & \\
\hline $\begin{array}{l}\mathrm{N} 1-\mathrm{Pd}-\mathrm{N} 2 \\
\mathrm{C} 1-\mathrm{Pd}-\mathrm{N} 2\end{array}$ & & $\begin{array}{l}99.05(11) \\
87.3(2)\end{array}$ & & & & & & & \\
\hline $\mathrm{N} 2-\mathrm{Pd}-\mathrm{P} 1$ & & $173.61(9)$ & & & & & & & \\
\hline $\mathrm{N} 1-\mathrm{Pd}-\mathrm{P} 2$ & & & 101.29(13) & & & & & & \\
\hline $\begin{array}{l}\mathrm{C} 1-\mathrm{Pd}-\mathrm{P} 2 \\
\mathrm{P} 2-\mathrm{Pd}-\mathrm{P} 1\end{array}$ & & & $87.7(2)$ & & & & & & \\
\hline $\begin{array}{l}\mathrm{P} 2-\mathrm{Pd}-\mathrm{P} 1 \\
\mathrm{~N} 1-\mathrm{Pd}-\mathrm{O} 1\end{array}$ & & & 163.97(7) & & $103.53(12)$ & & & & $3(13)$ \\
\hline $\mathrm{C} 1-\mathrm{Pd}-\mathrm{O} 1$ & & & & & $80.9(2)$ & $\begin{array}{l}101.8(3) \\
81.3(4)\end{array}$ & $\begin{array}{l}103.39(11) \\
80.0(2)\end{array}$ & $\begin{array}{l}99.2 /(10) \\
81.68(13)\end{array}$ & $\begin{array}{l}99.03(13) \\
83.5(2)\end{array}$ \\
\hline $\mathrm{O} 1-\mathrm{Pd}-\mathrm{P} 1$ & & & & & 172.79(9) & $176.5(3)$ & $171.31(8)$ & $168.34(8)$ & $173.44(9)$ \\
\hline
\end{tabular}

Scheme 1<smiles></smiles>

1<smiles>CN(C)[P+]1(Br)NCCP1[P+](C)(C)c1ccccc1</smiles>

2

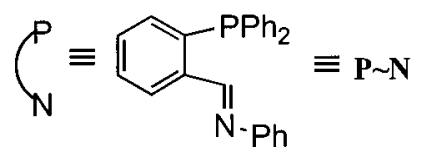

ether. Selected IR and NMR data of the complexes are also shown in Table 1.

The presence of two low-intensity bands at 2322 and $2289 \mathrm{~cm}^{-1}$ in the IR spectrum, which are assigned to the coordinated acetonitrile, is comparable to the reported palladium complexes. ${ }^{13 a}$ Phosphorus-31 NMR again shows only one signal corresponding to the formation of a single isomer. The peaks are slightly downfield shifted (1-2 ppm) compared to the less electrophilic neutral analogues. A slightly smaller hydrogen-phosphorus coupling $\left(\mathrm{P}_{\mathrm{P}-\mathrm{H}} \approx 1.6 \mathrm{~Hz}\right)$ for the methyl hydrogen atoms is observed. ${ }^{13 a} \mathrm{X}$-ray structural analysis of $\mathbf{2}$ (Figure 2) also confirms the cis-arrangement of phosphine and methyl group and the coordination of acetonitrile to palladium as well. Selected bond lengths and angles are given in Table 2. The triphenylphosphinesubstituted complex $\mathbf{3}$ was prepared by substitution reaction of $\mathbf{2}$ with $\mathrm{PPh}_{3}$ in dichloromethane solution, and its characterization was performed by both ${ }^{1} \mathrm{H}$ and ${ }^{31} \mathrm{P}$ NMR spectroscopy (Table 1). ${ }^{21}$ In addition, the X-ray structure of $\mathbf{3}$ (Figure 3) was obtained.

CO and Ethylene Insertions into Neutral and Cationic Palladium Complexes. Insertion reactions of $\mathrm{CO}$ into the $\mathrm{Pd}-\mathrm{C}$ bond for complexes $\mathbf{1}-\mathbf{3}$ were monitored by ${ }^{31} \mathrm{P}$ NMR. In a typical experiment, a $\mathrm{CDCl}_{3}$ solution of the respective complex (10-15 mg) was bubbled with $\mathrm{CO}$ for $30 \mathrm{~min}$, and the ${ }^{31} \mathrm{P}$ NMR and ${ }^{1} \mathrm{H}$

(21) Crociani, L.; Bandoli, G.; Dolmella, A.; Basato, M.; Corain, B. Eur. J . Inorg. Chem. 1998, 1811.

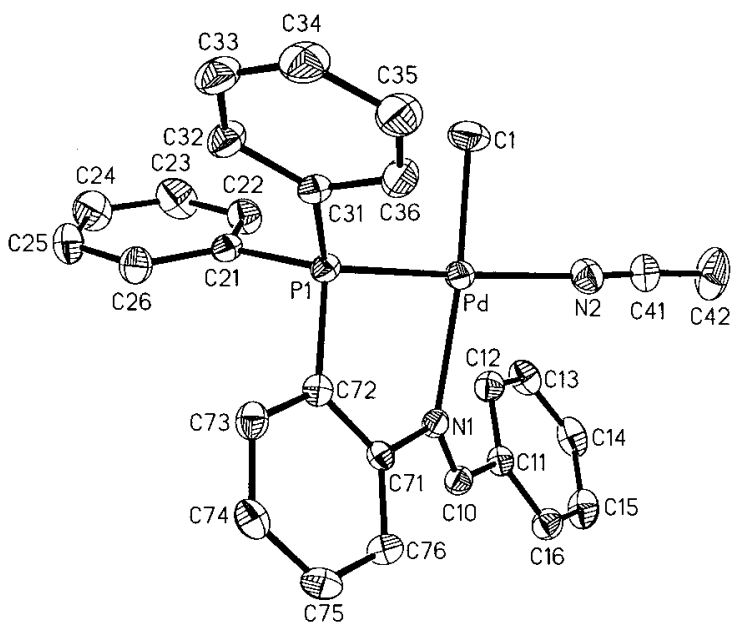

Figure 2. Molecular diagram of the cation $[(\mathbf{P} \sim \mathbf{N}) \mathrm{Pd}(\mathrm{Me})$ $\left.\left(\mathrm{NCCH}_{3}\right)\right]^{+}$.

NMR indicated the formation of the acyl product. The resulting acyl complexes 4-6 were isolated in stable solid form as described in Experimental Section. Selected spectroscopic data for the acyl derivatives are shown in Table 3.

Infrared absorption for the $\mathrm{C}=\mathrm{O}$ stretching band appears in the range $1688-1705 \mathrm{~cm}^{-1}$, which is typical for the acyl complexes. ${ }^{13 a}$ 31P NMR signals for 4-6 suggest the formation of one inserted product in each case. It is noticed that complex $\mathbf{5}$ exhibits relatively 


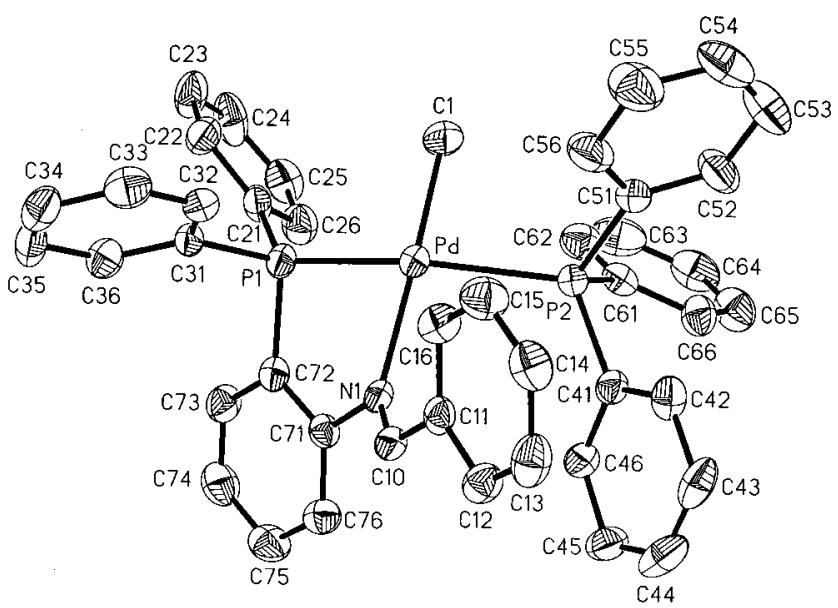

Figure 3. Structure of complex 3.

Table 3. Selected IR and NMR Data of the Inserted Productsa,b

\begin{tabular}{|c|c|c|c|c|}
\hline & $\begin{array}{c}\mathrm{C}=\mathrm{O}^{\mathrm{c}} \\
\nu\left(\mathrm{cm}^{-1}\right)\end{array}$ & ${ }^{1} \mathrm{H} N M R$ Pd-R & $-\mathrm{HC}=\mathrm{N}$ & ${ }^{31} \mathrm{P} N M R$ \\
\hline $\begin{array}{l}4 \\
5 \\
6\end{array}$ & $\begin{array}{l}1688 \\
1705 \\
1694\end{array}$ & $\begin{array}{l}2.23\left(\mathrm{~s},-\mathrm{COCH}_{3}\right) \\
1.76\left(\mathrm{~s},-\mathrm{COCH}_{3}\right) \\
1.79(\mathrm{~s})\end{array}$ & $\begin{array}{l}8.55(\mathrm{~m}) \\
9.11(\mathrm{~s}) \\
8.62(\mathrm{~s})\end{array}$ & $\begin{array}{c}14.8 \\
18.4 \\
16.5 \text { and } 12.5 \\
\text { (2 } \mathrm{PP}=250)\end{array}$ \\
\hline 7 & 1636 & $\begin{array}{l}1.86(\mathrm{t}, \mathrm{J}=7.0 \\
\left.\mathrm{Pd}-\mathrm{CH}_{2}\right)\end{array}$ & 9.15 (s) & 36.7 \\
\hline 8 & & $2.72\left(\mathrm{~s},-\mathrm{COCH}_{2}\right)$ & 9.07 (s) & 19.9 \\
\hline 9 & $\begin{array}{l}1712 \text { (f) } \\
1629 \text { (c) }\end{array}$ & $\begin{array}{l}1.89(\mathrm{~m}, 5 \mathrm{H} \\
\left.\quad \mathrm{CH}_{2}, \mathrm{CH}_{3}\right)\end{array}$ & 9.20 (s) & 36.8 \\
\hline 10 & 1630 & $\begin{array}{l}0.93(\mathrm{t}, 3 \mathrm{H})(\mathbf{1 0 a}) \\
1.33(\mathrm{~d}, 3 \mathrm{H})(\mathbf{1 0 b})\end{array}$ & $\begin{array}{l}9.14 \\
9.18\end{array}$ & $\begin{array}{l}36.3 \\
39.5\end{array}$ \\
\hline 11 & $\begin{array}{l}1708, \\
1686(f) \\
1630 \text { (c) }\end{array}$ & $2.51(\mathrm{~s}, \mathrm{Pd}-\mathrm{CH})$ & 9.29 (s) & 37.3 \\
\hline 12 & 1610 (c) & $3.46(\mathrm{~m}, \mathrm{Pd}-\mathrm{CH})$ & $9.11(\mathrm{~s})$ & 31.2 \\
\hline 13 & 1626 (c) & $1.32(\mathrm{~d}, \mathrm{Pd}-\mathrm{CH})$ & 9.19 (s) & 35.3 \\
\hline 14 & $\begin{array}{l}1713(f) \\
1610(c)\end{array}$ & $5.15(\mathrm{~s}, \mathrm{Pd}-\mathrm{CH})$ & 9.15 (s) & 35.7 \\
\hline $\begin{array}{l}15 \\
16\end{array}$ & 1620 (c) & $\begin{array}{l}5.27(\mathrm{~s}, \mathrm{Pd}-\mathrm{CH}) \\
1.83\left(\mathrm{t}, \mathrm{Pd}-\mathrm{CH}_{2}\right)\end{array}$ & $\begin{array}{l}9.30(\mathrm{~s}) \\
9.26(\mathrm{~s})\end{array}$ & $\begin{array}{l}34.7 \\
37.7\end{array}$ \\
\hline
\end{tabular}

a In $\mathrm{KBr}$. bln $\mathrm{CDCl}_{3}$, in ppm, J in $\mathrm{Hz} .{ }^{\mathrm{c}}(\mathrm{f})$ free carbonyl, (c) coordinated carbonyl.

better stability and can be isolated at room temperature and kept at $0{ }^{\circ} \mathrm{C}$ for several days.

Insertion of ethylene into the palladium-acyl bond was achieved by bubbling ethylene through a solution of dichloromethane containing the complex 5. The NMR spectrum of the resulting reaction mixture was taken immediately. Complete conversion of $\mathbf{5}$ into $\mathbf{7}$ was done within $1 \mathrm{~h}$. The 31P NMR spectrum shows a downfield shift representing the palladium-alkyl bond formation. Appearance of one ${ }^{31} \mathrm{P}$ signal indicates the formation of only one isomer. The IR spectrum shows a $C=O$ stretching band at $1636 \mathrm{~cm}^{-1}$, which is shifted about $70 \mathrm{~cm}^{-1}$ to lower wavenumber with respect to that of $5,{ }^{5 i, 6 e}$ indicating the coordination of the acyl-oxygen to the palladium center. Both ${ }^{1} \mathrm{H}$ and ${ }^{13} \mathrm{C}$ NMR support the formation of the insertion products (Table 3 ). It is noticed that the compound $\mathbf{7}$ is much more stable than the acyl complex $\mathbf{5}$ presumably due to the chelation effect. The detailed structure of $\mathbf{7}$ is confirmed by its $X$-ray single-crystal structural analysis (Figure 4). No insertion of the ethylene molecule into the $\mathrm{Pd}$-acyl bond of $\mathbf{4}$ and $\mathbf{6}$ was observed. Bubbling for a longer period $(\sim 24 \mathrm{~h}$ ) resulted in the precipitation of palladium black.

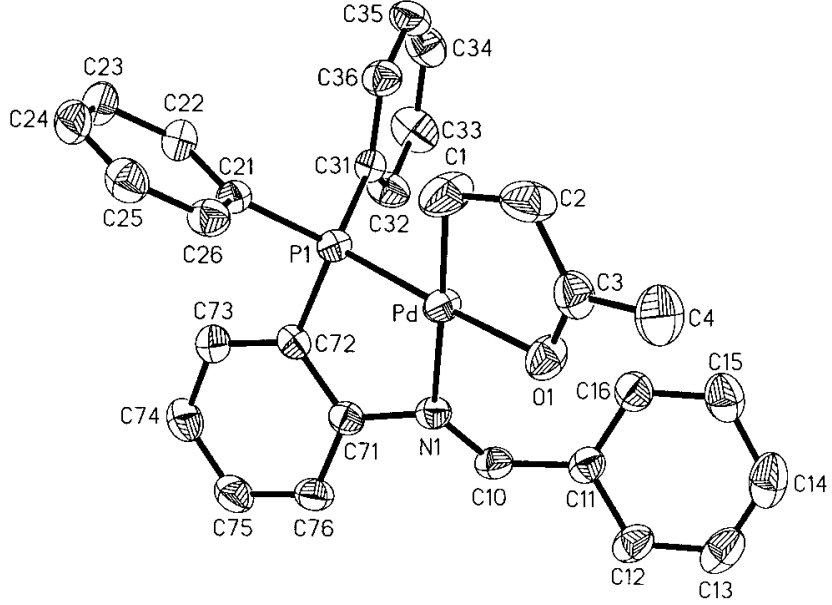

Figure 4. ORTEP plot of complex 7.

Further $\mathrm{CO}$ insertion into $\mathbf{7}$ in dichloromethane was not successful, but could be done in acetonitrile or a mixture of acetonitrile and dichloromethane. Apparently, the coordinating solvent is necessary to stabilize the resulting acyl product, as observed in prior cases. ${ }^{13 \mathrm{~d}}$ The crystal structures of complex $\mathbf{8}$ and the subsequent ethylene-inserted one $\mathbf{9}$ have been reported in our preliminary communication, Scheme $2 .{ }^{15}$ The $\mathrm{Pd}-\mathrm{C} 1$ bond distances in 7 [2.022(5) $\AA]$ and 9 [2.003(9) $\AA]$ are comparable with those in the diimine analogues, and the $\mathrm{Pd}-\mathrm{O} 1$ bond distances in $7[2.143(3) \AA]$ and $\mathbf{9}[2.127$ (4) $\AA$ ] are in agreement with those in the diphosphine complexes. ${ }^{6 e, 22}$ The formation of a five-membered $(C, O)$ chelation product via ol efin insertions into the $\mathrm{Pd}$-acyl bond is known. ${ }^{2 \mathrm{C}} \mathrm{N}$ everthel ess further insertion by $\mathrm{CO}$ and the fact that it serves as a catalyst for $\mathrm{CO} /$ ethylene copolymerization in complex $\mathbf{9}$ indicate that the phosphine-imine system may be promising for the use of insertion processes. ${ }^{15}$

Insertion of F unctionalized Olefins into 5. Insertion of propene with $\mathbf{5}$ leads to the formation of two mixed species (10a and $\mathbf{1 0 b})$ in 1:1 ratio according to the ${ }^{1} \mathrm{H}$ and ${ }^{31} \mathrm{P}$ NMR spectroscopic data. On the other hand, complex 5 undergoes regiospecific insertions (2,1insertion) with methyl acrylate or styrene to provide $\mathbf{1 1}$ and 12, respectively, as shown in Scheme 3 . The insertion of norbornene into 5 proceeds exclusively from the exo-face to give the product $\mathbf{1 3}$. Such face-selective insertion of norbornene into the Pd-acyl bond was also observed with bidentate nitrogen and bis(phosphine) complexes earlier. $6 e, 22$ The complexes 10-13 are isolated in solid form and characterized by spectroscopic methods (Table 3) and by X-ray structural analysis. The molecular structure of $\mathbf{1 3}$ is ill ustrated in Figure 5, and selected bond distances and angles are summarized in Table 2.

It is generally known that olefin insertion into a Pdacyl bond is faster than into the Pd-alkyl bond. Experimental evidence also suggests that the formation of the five-membered $(\mathrm{C}, \mathrm{O})$ chelation product provides the extra stability to avoid competing $\beta$-hydride elimination. In all instances investigated in this work, consecutive insertion of al kene molecules is not feasible, i.e., no insertion of alkene into $\mathrm{Pd}-\mathrm{C}_{(\text {alkyl), }}$ except that

(22) Brumbaugh, J . S.; Whittle, R. R.; Parvez, M.; Sen, A. Organometallics 1990, 98, 1735. 
Scheme 2

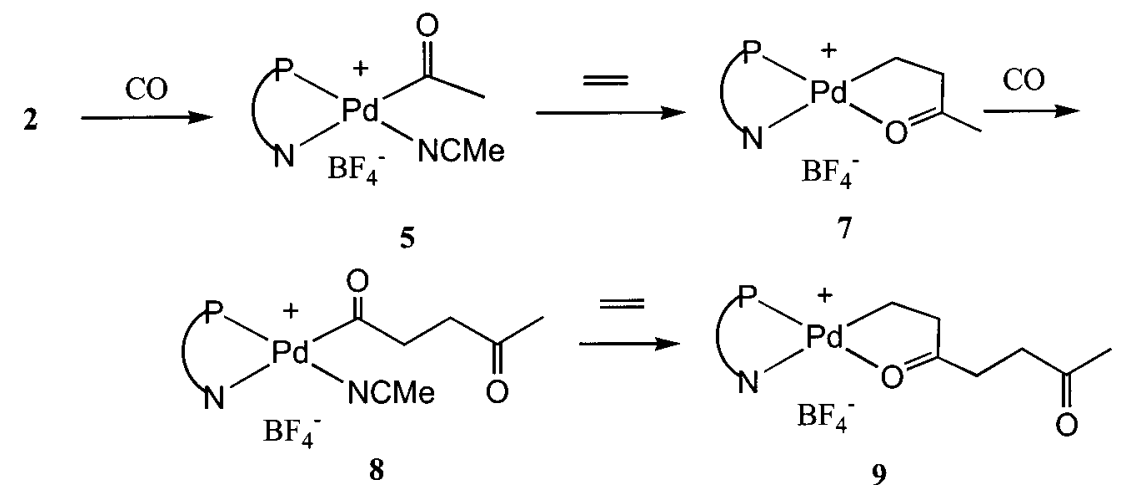

Scheme 3

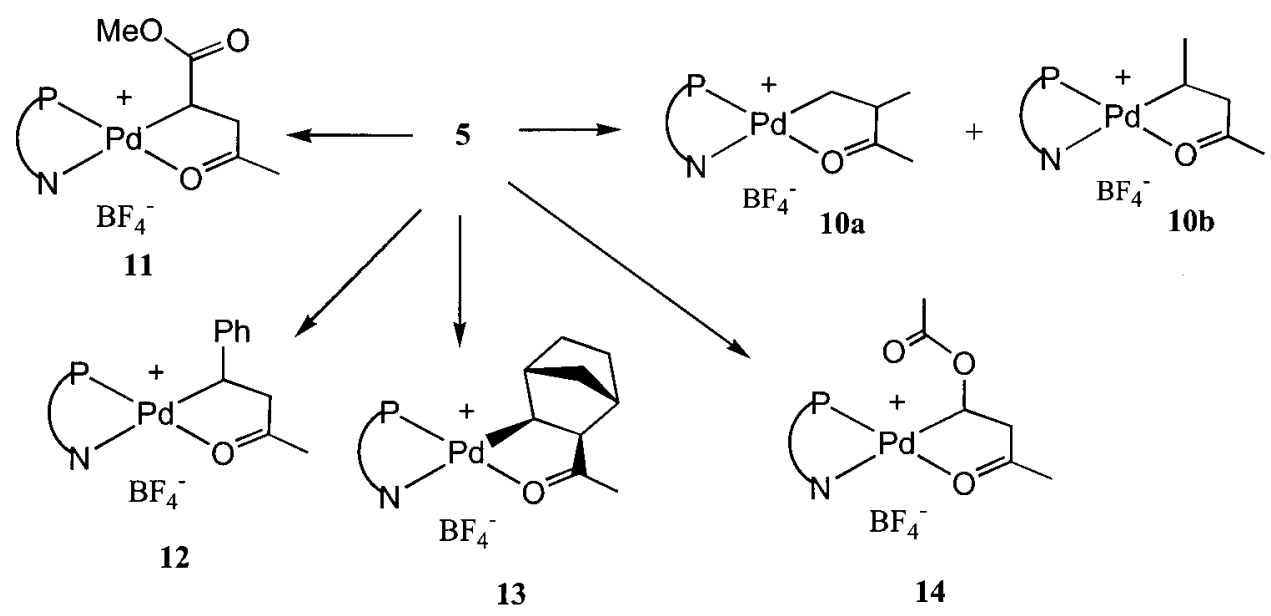

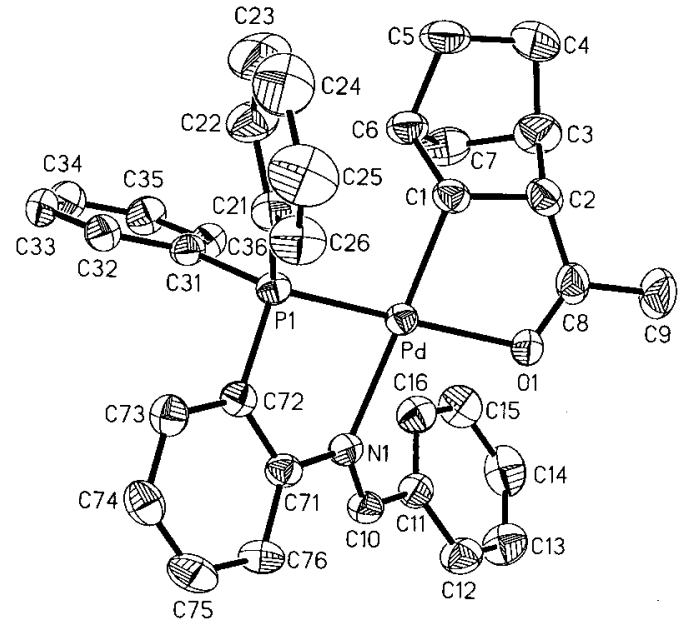

Figure 5. Structure of complex 13.

vinyl acetate can insert into 5 and $\mathbf{2}$ to yield $\mathbf{1 4}$ and $\mathbf{1 5}$, respectively. ${ }^{15}$<smiles></smiles>

15

Copolymerization. Taking advantage of the feasibility of the stepwise insertion of CO/ethylene (E-CO) in $\mathbf{2}$, the use of $\mathbf{2}$ as the catalyst for copolymerization is investigated. In an autoclave was placed the $27 \mathrm{mg}$ of catalyst in dichloromethane $(70 \mathrm{~mL})$, and 40 psi each of $\mathrm{CO}$ and ethylene was stirred at room temperature for $48 \mathrm{~h}$. The resulting white solid was filtered and washed with $5 \mathrm{~N} \mathrm{HCl}$, followed by water and acetone, respectively. A small amount of polymer product (440 $\mathrm{mg}$ ) was formed. It appears that complex $\mathbf{2}$ is not a very efficient catalyst for E-CO copolymerization. However, such reaction allows us to isolate the rare species of a metal-capped E-CO copolymer. The reaction proceeds at room temperature for $4 \mathrm{~h}$, and an E-CO oligomeric palladium complex $\mathbf{1 6}$ was acquired. It was characterized by spectroscopic methods. ${ }^{1} \mathrm{H}$ NMR and mass spectra are shown in Figures 6 and 7, which clearly evidence the attached ethylene/CO oligomeric units to palladium metal. By NMR integration, the average repeating units of each chain have been estimated to be 14 .

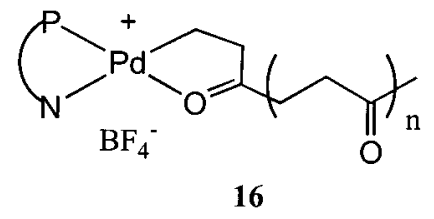

\section{Discussion}

In this work, we demonstrate that the unsymmetric $\mathbf{P} \sim \mathbf{N}$ bidentate tends to allow single regioisomers in each insertion process. Since the migratory insertion could change the coordination site for the carbon-bound ligand, one might expect to see the kinetic products with the carbon ligand being trans or cis to phosphine. 

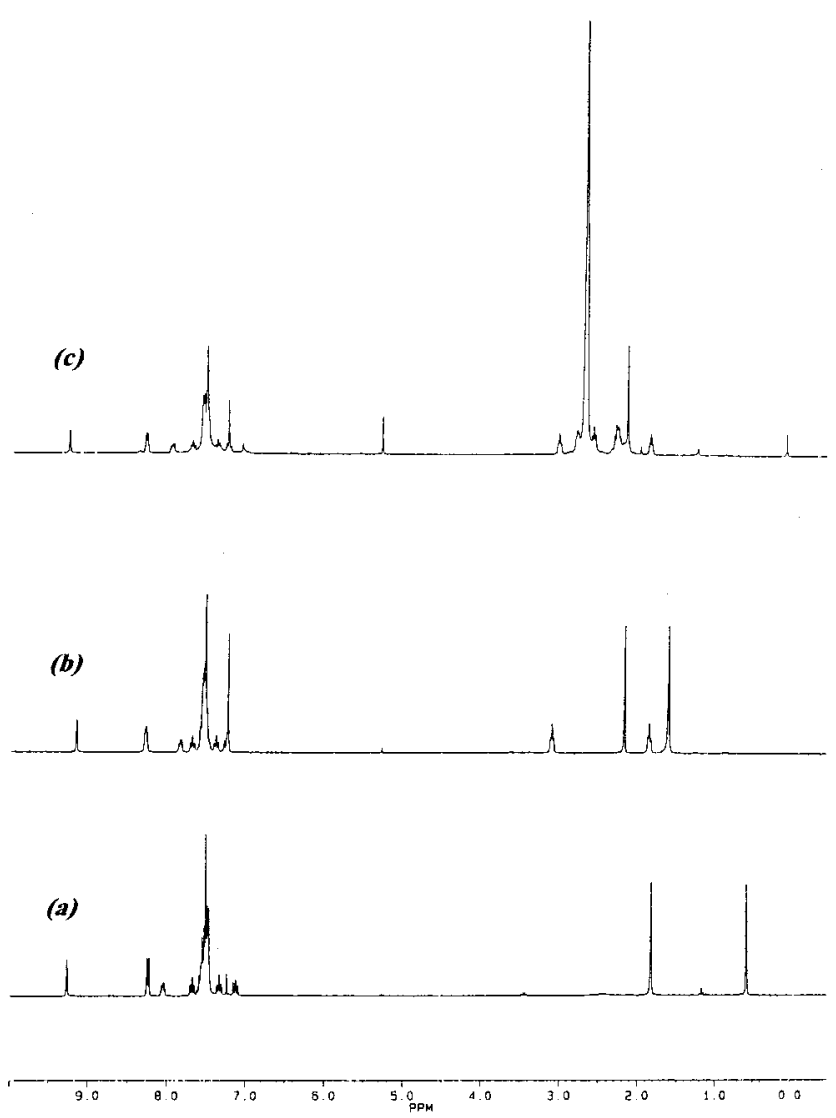

Figure 6. (a) ${ }^{1} \mathrm{H}$ NMR spectrum of complex 2. (b) ${ }^{1} \mathrm{H} N M R$ spectrum of complex 7. (c) ${ }^{1} \mathrm{H}$ NMR spectrum of complex 16, the metal-capped oligomer.
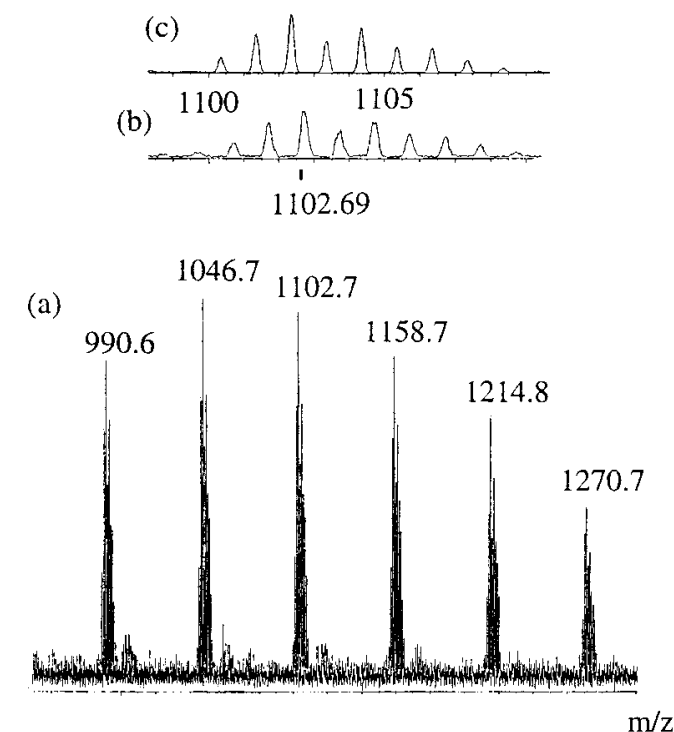

Figure 7. (a) $F A B$ mass spectrum of complex $\mathbf{1 6}$ in the range $\mathrm{m} / \mathrm{z}$ 900-1300. (b) Expansion of $\mathrm{m} / \mathrm{z}$ at 1102 , which is consistent with formula of $\left[(\mathbf{P} \sim \mathbf{N}) \mathrm{Pd}\left(\mathrm{CH}_{2} \mathrm{CH}_{2} \mathrm{CO}\right)_{11} \mathrm{CH}_{3}\right]^{+}$. (c) Simulated pattern of the formula of $\left[(\mathbf{P} \sim \mathbf{N}) \mathrm{Pd}\left(\mathrm{CH}_{2} \mathrm{CH}_{2^{-}}\right.\right.$ CO) $\left.{ }_{11} \mathrm{CH}_{3}\right]^{+}$.

However, only one of that kind of intermediate with a carbon ligand cis to phosphine is observed in our studies. This is similar to the carbonylation of other known $\mathrm{P}-\mathrm{N}$ palladium complexes ${ }^{13 a, d}$ and suggests that a rapid isomerization process must occur during the insertion steps. This outcome is consistent with Pearson's antisymbiotic effect. ${ }^{23}$
The Pd-acyl complexes with weak coordinating ligands such as acetonitrile can be subjected to decarbonylation, which accounts for the unstable nature of some Pdacyl complexes. ${ }^{5 d, 6 e, g, 10 a}$ The deinsertion process can be hindered by strongly coordinating or inert ligands such as chloride or phosphines. Indeed, acyl complexes $\mathbf{4}$ and 6 are found to be stable at $25^{\circ} \mathrm{C}$. Curiously, the cationic palladium acyl complex $\mathbf{5}$ with a weak coordinating acetonitrile is stable and allows us to utilize it for further studies of alkene and alkyne insertions. ${ }^{15} \mathrm{Lu}$ instra and co-workers also demonstrated the isolation of CO-inserted products with mixed bidentate $\mathrm{P}-\mathrm{N}$ ligands. ${ }^{13 a}$ Like compound 5 , the stable $\mathrm{Pd}-$ acyl complex $\mathbf{1 7}$ with an unsymmetric $\mathrm{P}-\mathrm{O}$ ligand was reported by Braunstein and co-workers recently. ${ }^{11 a}$ In fact, we demonstrated that the metal-capped polymeric species 16 can be isolated under copolymerization conditions, indicating that the $\mathbf{P} \sim \mathbf{N}$ bidentate plays a role in stabilization of the palladium-attached carbon ligand, which also explains the lower catalytic activity in copoylermization; that is, every metal center can carry only one polymer chain.<smiles>CCC[Pb](N(C)C)(N(C)C)[P+]1(c2ccccc2)NC(C)=NP1</smiles>

17

Complex $\mathbf{5}$ shows reactivity toward insertion with various alkenes. $\alpha$-Olefins such as styrene, methyl acrylate, or vinyl acetate undergo a regioselective insertion (2,1-insertion). Norbornylene undergoes insertion selectively at the exo-face. Only propene gives a mixture of 1,2- and 2,1-inserted products. This selectivity is consistent with most of the other insertion instances, in which the coordinating orientation of the ol efin would determine the regio- or stereoproperties of the products.

Unlike the diimine-palladium complexes, neither $\mathbf{2}$ nor $\mathbf{5}$ can serve as a polymerization catalyst for olefins, even for ethylene. Our previous study indicates that complex $\mathbf{2}$ mediates the dimerization and trimerization of ethylene, ${ }^{24}$ but shows no reactivity toward propene or styrene. On the other hand, alternating insertion of $\mathrm{CO}$ and ol efins in $\mathbf{2}$ or $\mathbf{5}$ is facile, indicating the greater activation barrier for ol efin insertion than that of $\mathrm{CO}$ insertion reactions. ${ }^{5 a, 6 d}$

The crystallographic results in this work confirm that the ligands of the $\mathrm{P}, \mathrm{N}$ chelates al ways have the carbon ligand seated trans to the imine donors. The configurations of the coordinating atoms in complexes are in typical square planar geometry, as expected. The bond distances and bond angles are in the normal range, except the angles of $\mathrm{N}-\mathrm{Pd}-\mathrm{P}$ (Tables 2 ) are smaller, due to o-phenylene linkage. Whether the angle of $\mathrm{N}-\mathrm{Pd}-\mathrm{P}$ is related to the activity of insertion is currently under investigation.

\section{Conclusion}

The designed $\mathrm{P} \sim \mathrm{N}$ ligand in this work allows the formation of a stable five-membered chelation product

(23) Pearson, R. G. Inorg. Chem. 1973, 12, 712.

(24) Chen, J .-T.; Liu, S.-T.; Zhao, K.-Q. J . Chin. Chem. Soc. 2000 $47,279$. 
with palladium complexes. The mixed soft and hard donors of phosphorus and nitrogen in the palladium complexes influence the binding stability of the substrates and ligand migration and results in the isolation of various new inserted intermediates, including a rare palladium-capped oligomer. This result allows the opportunity to build block polymerizations.

\section{Experimental Section}

General Information. All reactions, manipulations, and purifications steps were performed under a dry nitrogen atmosphere. Tetrahydrofuran was distilled under nitrogen from sodium benzophenone ketyl. Dichloromethane and acetonitrile were dried with $\mathrm{CaH}_{2}$ and distilled under nitrogen. Other chemicals and solvents were of analytical grade and were used as received unless otherwise stated. 2-(Diphenylphosphino)aniline and $\mathrm{Pd}(\mathrm{COD}) \mathrm{MeCl}$ were prepared according to literature procedures. ${ }^{16,17}$

Nuclear magnetic resonance spectra were recorded in $\mathrm{CDCl}_{3}$ on either a Bruker AC-E 200 or AM-300 spectrometer. Chemical shifts are given in parts per million relative to $\mathrm{Me}_{4} \mathrm{~S}$ for ${ }^{1} \mathrm{H}$ and relative to $85 \% \mathrm{H}_{3} \mathrm{PO}_{4}$ for ${ }^{31} \mathrm{P} \mathrm{NMR}$. I nfrared spectra were measured on a Nicolet Magna-IR 550 spectrometer (Series II) as KBr pallets, unless otherwise noted.

Synthesis of $\mathbf{P} \sim \mathbf{N}$ Ligand. To freshly distilled benzaldehyde (16 mL, $0.15 \mathrm{~mol}$ ) was added 2-(diphenylphosphino)aniline $(6.0 \mathrm{~g}, 0.02 \mathrm{~mol})$ under nitrogen, and the mixture was stirred at room temperature under vacuum. Completion of the reaction was monitored by ${ }^{31} \mathrm{P} N \mathrm{NMR}$, which took $6-7 \mathrm{~h}$. The reaction mixture was poured into cold methanol and kept at low temperature overnight. The desired ligand $\mathbf{P} \sim \mathbf{N}$ was crystallized as a white solid $(5.2 \mathrm{~g}, 65 \%)$. IR (KBr): $1625 \mathrm{~cm}$ ${ }^{-1}(\mathrm{C}=\mathrm{N}) .{ }^{1} \mathrm{H}$ NMR $\left(\mathrm{CDCl}_{3}\right): \delta 6.84-7.31(\mathrm{~m}, 17 \mathrm{H}), 7.63(\mathrm{~m}, 2$ $\mathrm{H}), 8.12(\mathrm{~s}, 1 \mathrm{H})$. 31P NMR $\left(\mathrm{CDCl}_{3}\right): \delta-14.5$. Anal. Calcd for $\mathrm{C}_{25} \mathrm{H}_{20} \mathrm{NP}$ : C 82.17; $\mathrm{H}, 5.52 ; \mathrm{N}, 3.83$. Found: $\mathrm{C}, 81.84 ; \mathrm{H}, 5.79$; $\mathrm{N}$, 3.67. FABMS: $366\left(\mathrm{M}^{+}\right)$.

Complex 1. To a colorless solution of Pd(COD)MeCl (265 $\mathrm{mg}, 1 \mathrm{mmol}$ ) in THF ( $5 \mathrm{~mL}$ ) was added an equal molar amount of the ligand in a THF solution ( $5 \mathrm{~mL}$ ). The mixture was stirred under $\mathrm{N}_{2}$ at room temperature. After $15 \mathrm{~min}$ a white solid began to precipitate, and the solution was stirred for another $30 \mathrm{~min}$. The resulting mixture was cooled, and the white solid was filtered and washed with ether and dried under vacuum (470 mg, 90\%). IR ( $\mathrm{KBr}): 1611(\mathrm{C}=\mathrm{N}) .{ }^{1} \mathrm{H}$ NMR $\left(\mathrm{CDCl}_{3}\right): \delta$ $0.88(\mathrm{~d}, 3 \mathrm{H}, \mathrm{J}=2.9 \mathrm{~Hz}), 7.13-7.60(\mathrm{~m}, 17 \mathrm{H}), 8.53(\mathrm{~m}, 2 \mathrm{H})$, $8.62(\mathrm{~s}, 1 \mathrm{H}) .{ }^{13} \mathrm{C} \mathrm{NMR}\left(\mathrm{CDCl}_{3}\right): \delta 0.87(\mathrm{Pd}-\mathrm{Me}), 168.9(\mathrm{C}=\mathrm{N})$. ${ }^{31} \mathrm{P}$ NMR $\left(\mathrm{CDCl}_{3}\right): \delta$ 35.4. Anal. Calcd for $\mathrm{C}_{26} \mathrm{H}_{23} \mathrm{NPClPd}$ : C, 59.8, H, 4.43, N, 2.68. Found: C, 59.9; H, 4.78; N, 2.28.

Complex 2. To a solution of the neutral complexes $\mathbf{1}(0.5$ $\mathrm{mmol}$ ) in $20 \mathrm{~mL}$ of $\mathrm{CH}_{2} \mathrm{Cl}_{2}$ was added a stoichiometric amount of $\mathrm{AgBF}_{4}$ in $5 \mathrm{~mL}$ of $\mathrm{CH}_{3} \mathrm{CN}$ under nitrogen, and the reaction mixture was stirred at room temperature for $1 \mathrm{~h}$. The resulting white $\mathrm{AgCl}$ precipitate was filtered through silica gel, and the solvent was evaporated to a small amount. U pon addition to $\mathrm{Et}_{2} \mathrm{O}$, a precipitate was deposited, which was filtered and dried under vacuum, resulting in $262 \mathrm{mg}(85 \%)$ of pure product. IR $(\mathrm{KBr}): 1609(\mathrm{C}=\mathrm{N}), 2322$ and $2289(\mathrm{C} \equiv \mathrm{N}){ }^{1}{ }^{\mathrm{H}} \mathrm{NMR}\left(\mathrm{CDCl}_{3}\right)$ : $\delta 0.58(\mathrm{~d}, 3 \mathrm{H}, \mathrm{J}=1.60 \mathrm{~Hz}), 1.80(\mathrm{~s}, 3 \mathrm{H}), 7.09-8.04(\mathrm{~m}, 17$ $\mathrm{H}), 8.23(\mathrm{~d}, 2 \mathrm{H}, \mathrm{J}=7.0 \mathrm{~Hz}), 9.26(\mathrm{~s}, 1 \mathrm{H}) .{ }^{13} \mathrm{C} \mathrm{NMR}\left(\mathrm{CDCl}_{3}\right)$ : $\delta-2.09(\mathrm{Pd}-\mathrm{Me}), 1.81(\mathrm{Pd}-\mathrm{NCMe}), 169.6(\mathrm{C}=\mathrm{N}) .{ }^{31} \mathrm{P} \mathrm{NMR}$ $\left(\mathrm{CDCl}_{3}\right): \delta$ 38.6. Anal. Calcd for $\mathrm{C}_{28} \mathrm{H}_{26} \mathrm{~N}_{2} \mathrm{PBF}_{4} \mathrm{Pd}$ : C, 54.70; $\mathrm{H}, 4.26 ; \mathrm{N}, 4.55$. Found: $\mathrm{C}, 54.66 ; \mathrm{H}, 4.17 ; \mathrm{N}, 4.36$. FABMS: $486.1\left(\mathrm{M}^{+}-\mathrm{CH}_{3} \mathrm{CN}\right)$.

Complex 3. To a solution of the cationic complexes $2(0.5$ $\mathrm{mmol}$ ) in $20 \mathrm{~mL}$ of THF was added a stoichiometric amount of $\mathrm{PPh}_{3}$ under nitrogen, and the reaction mixture was stirred for $1 \mathrm{~h}$. The solvent was removed under vacuum, and the residue was washed with $\mathrm{Et}_{2} \mathrm{O}$ and dried under vacuum, resulting in $355 \mathrm{mg}$ (85\%) of pure product. IR (KBr): 1610
$(\mathrm{C}=\mathrm{N}) .{ }^{1} \mathrm{H} \mathrm{NMR}\left(\mathrm{CDCl}_{3}\right): \delta 0.77(\mathrm{t}, 3 \mathrm{H}, \mathrm{J}=6.1 \mathrm{~Hz}), 7.0$ $7.82(\mathrm{~m}, 32 \mathrm{H}), 8.05(\mathrm{~d}, 2 \mathrm{H}, \mathrm{J}=6.8 \mathrm{~Hz}), 8.61(\mathrm{~s}, 1 \mathrm{H}) .{ }^{13} \mathrm{C}$ NMR $\left(\mathrm{CDCl}_{3}\right): \delta-0.16(\mathrm{Pd}-\mathrm{Me}), 172.1(\mathrm{C}=\mathrm{N}) .31 \mathrm{P}$ NMR $\left(\mathrm{CDCl}_{3}\right): \delta 30.8$ and $27.5\left(\mathrm{~d},{ }^{2} \mathrm{f} p \mathrm{pP}=381 \mathrm{~Hz}\right)$. Anal. Calcd for $\mathrm{C}_{44} \mathrm{H}_{38} \mathrm{NP}_{2} \mathrm{BF}_{4} \mathrm{Pd}$ : C, 63.20; $\mathrm{H}, 4.58 ; \mathrm{N}, 1.67$. Found: C, 62.98; $\mathrm{H}, 4.70 ; \mathrm{N}, 1.60$. FABMS: $749.1\left(\mathrm{M}^{+}\right)$.

General Procedure for Preparation of Complexes 4-6. To a solution of $\mathbf{1}-\mathbf{3}(0.25 \mathrm{mmol})$ in $10 \mathrm{~mL}$ of $\mathrm{CH}_{2} \mathrm{Cl}_{2}$, continuous bubbling of carbon monoxide for $2-4 \mathrm{~h}$ resulted in the formation of the corresponding CO-inserted product. The resulting solution was cooled and filtered through silica gel (small amount of Pd black formation was observed in all these reactions), and the filtrate was evaporated to a small volume. The desired complex was precipitated by addition of diethyl ether.

Complex 4. (80\%) IR (KBr): $1688(\mathrm{C}=\mathrm{O}), 1610 \mathrm{~s}(\mathrm{C}=\mathrm{N})$. ${ }^{1} \mathrm{H}$ NMR $\left(\mathrm{CDCl}_{3}\right): \delta 2.23(\mathrm{~s}, 3 \mathrm{H}), 7.23-7.64(\mathrm{~m}, 17 \mathrm{H}), 8.44$ $(\mathrm{m}, 1 \mathrm{H}), 8.55(\mathrm{~m}, 1 \mathrm{H}) .{ }^{31} \mathrm{P} \mathrm{NMR}\left(\mathrm{CDCl}_{3}\right): \delta 14.8$. Anal. Calcd for $\mathrm{C}_{27} \mathrm{H}_{23} \mathrm{NOPClPd}$ : C, 58.9; $\mathrm{H}, 4.21 ; 2.54$. Found: $\mathrm{C}, 58.35$; $\mathrm{H}, 4.41 ; \mathrm{N}, 2.34$.

Complex 5. $(75 \%)$ IR $(\mathrm{KBr}): 1705(\mathrm{C}=\mathrm{O}), 1610(\mathrm{C}=\mathrm{N}) .{ }^{1 \mathrm{H}}$ NMR $\left(\mathrm{CDCl}_{3}\right): \delta 1.76(\mathrm{~s}, 3 \mathrm{H}), 1.99(\mathrm{~s}, 3 \mathrm{H}), 7.18-7.70(\mathrm{~m}, 16$ $\mathrm{H}), 8.28(\mathrm{~s}, 1 \mathrm{H}), 8.46(\mathrm{~s}, 2 \mathrm{H}), 9.11(\mathrm{~s}, 1 \mathrm{H}) .{ }^{13} \mathrm{C} \mathrm{NMR}\left(\mathrm{CDCl}_{3}\right)$ : $\delta 2.0\left(\mathrm{Pd}-\mathrm{NCCH}_{3}\right), 37.3\left(\mathrm{COCH}_{3}\right), 169.4(\mathrm{C}=\mathrm{N}), 226.8$ (Pd-COMe). ${ }^{31} \mathrm{P} N M R\left(\mathrm{CDCl}_{3}\right): \delta$ 18.4. FABMS: $514\left(\mathrm{M}^{+}-\right.$ $\mathrm{CH}_{3} \mathrm{CN}$ )

Complex 6. (80\%) IR (KBr): $1694(\mathrm{C}=\mathrm{O}), 1608(\mathrm{C}=\mathrm{N}) .{ }^{1 \mathrm{H}}$ $\operatorname{NMR}\left(\mathrm{CDCl}_{3}\right): \delta 1.79(\mathrm{~s}, 3 \mathrm{H}), 7.14-7.83(\mathrm{~m}, 32 \mathrm{H}), 8.18(\mathrm{~d}, 2$ $\mathrm{H}, \mathrm{J}=6.7 \mathrm{~Hz}), 8.62(\mathrm{~s}, 1 \mathrm{H})$. ${ }^{31} \mathrm{P} \mathrm{NMR}\left(\mathrm{CDCl}_{3}\right): \delta 16.5$ and 12.5 (d, trans, 2) pp $=250 \mathrm{~Hz}$ ). Anal. Calcd for $\mathrm{C}_{45} \mathrm{H}_{38} \mathrm{NOP}_{2^{-}}$ $\mathrm{BF}_{4} \mathrm{Pd}$ : $\mathrm{C}, 62.5 ; \mathrm{H}, 4.43 ; \mathrm{N}, 1.62$. Found: $\mathrm{C}, 61.6 ; \mathrm{H}, 4.47 ; \mathrm{N}$, 1.57. FABMS: $777.1\left(\mathrm{M}^{+}\right)$.

Complex 7. To a solution of $\mathbf{5}(100 \mathrm{mg})$ in $5 \mathrm{~mL}$ of $\mathrm{CH}_{2} \mathrm{Cl}_{2}$ was bubbled ethylene for $1 \mathrm{~h}$. The resulting solution was filtered through silica gel and evaporated to a small volume. The desired product was precipitated by addition of $\mathrm{Et}_{2} \mathrm{O}$ (74 mg, 72\%). IR (KBr): $1636(\mathrm{C}=\mathrm{O}), 1609(\mathrm{C}=\mathrm{N}) .{ }^{1} \mathrm{H} N M R$ $\left(\mathrm{CDCl}_{3}\right): \delta 1.86\left(\mathrm{t}, 2 \mathrm{H}, \mathrm{J}=7.0 \mathrm{~Hz}, \mathrm{Pd}-\mathrm{CH}_{2}\right), 2.18(\mathrm{~s}, 3 \mathrm{H}$, $\left.\mathrm{COCH}_{3}\right), 3.10\left(\mathrm{t}, 2 \mathrm{H}, \mathrm{J}=7.0,-\mathrm{CH}_{2} \mathrm{CO}\right), 7.23-7.69(\mathrm{~m}, 17$ $\mathrm{H}), 8.29(\mathrm{~m}, 2 \mathrm{H}), 9.15(\mathrm{~s}, 1 \mathrm{H}) .{ }^{13} \mathrm{C} \mathrm{NMR}\left(\mathrm{CDCl}_{3}\right): \delta 21.6$ $\left(\mathrm{Pd}-\mathrm{CH}_{2}\right), 27.5\left(\mathrm{COCH}_{3}\right), 50.4\left(\mathrm{CH}_{2}-\mathrm{CO}\right), 232.9\left(\mathrm{CH}_{3} \mathrm{COCH}_{2}\right)$. 31P NMR $\left(\mathrm{CDCl}_{3}\right): \delta$ 36.7. Anal. Calcd for $\mathrm{C}_{30} \mathrm{H}_{29} \mathrm{NOPBF}_{4} \mathrm{Pd}$ : C, 56.49; H, 4.58; N, 2.19. Found: C, 55.54; H, 4.37; N, 2.21. FABMS: $550.9\left(\mathrm{M}^{+}\right)$.

Complex 8. To a solution of $\mathbf{7}(50 \mathrm{mg})$ in $2 \mathrm{~mL}$ of $\mathrm{CH}_{3} \mathrm{CN}$ was bubbled carbon monoxide for $1 \mathrm{~h}$, and the resulting solution was filtered through silica gel and evaporated to a small amount at low temperature and precipitated by adding to an $\mathrm{Et}_{2} \mathrm{O}$ solution. The resulting pale yellow solid was filtered and dried under vacuum. ${ }^{1} \mathrm{H}$ NMR $\left(\mathrm{CDCl}_{3}\right): \delta 1.77(\mathrm{~s}, 3 \mathrm{H}$, $\left.\mathrm{Pd}-\mathrm{NCCH}_{3}\right), 1.94\left(\mathrm{~s}, 3 \mathrm{H}, \mathrm{COCH}_{3}\right), 2.26(\mathrm{br}, 2 \mathrm{H}, \mathrm{PdCOCH})_{2}$, $2.72\left(\mathrm{br}, 2 \mathrm{H}, \mathrm{COCH}_{2} \mathrm{CH}_{2}\right), 7.19-7.69(\mathrm{~m}, 16 \mathrm{H}), 7.89(\mathrm{~s}, 1 \mathrm{H})$, $8.26(\mathrm{~s}, 2 \mathrm{H}), 9.07(\mathrm{~s}, 1 \mathrm{H}) .{ }^{13} \mathrm{C} \mathrm{NMR}\left(\mathrm{CDCl}_{3}\right): \delta 29.3\left(\mathrm{COCH}_{3}\right)$, 37.4 $\left(\mathrm{CH}_{2} \mathrm{CO}\right), 44.5\left(\mathrm{PdCOCH}_{2}\right), 206.6\left(\mathrm{COCH}_{3}\right), 223.1(\mathrm{PdCO})$. ${ }^{31} \mathrm{P} \mathrm{NMR}\left(\mathrm{CDCl}_{3}\right): \delta 19.9$.

Complex 9. To a $\mathrm{CH}_{2} \mathrm{Cl}_{2}$ solution of the above complex 8 was bubbled ethylene gas for $2 \mathrm{~h}$. The solution was filtered through silica gel, concentrated to a small amount, and precipitated by adding to an $\mathrm{Et}_{2} \mathrm{O}$ solution. The solid was filtered and dried under vacuum. IR ( $\mathrm{KBr})$ : $1712(\mathrm{C}=\mathrm{O}$, free), $1629(\mathrm{C}=\mathrm{O}$, coordinated $), 1609(\mathrm{C}=\mathrm{N}) .{ }^{1} \mathrm{H}$ NMR $\left(\mathrm{CDCl}_{3}\right): \delta$ $1.89\left(\mathrm{~m}, 5 \mathrm{H}, \mathrm{COCH}_{3}+\mathrm{PdCOCH}_{2}\right), 2.32(\mathrm{t}, 2 \mathrm{H}, \mathrm{J}=7 \mathrm{~Hz})$, $2.77(\mathrm{t}, 2 \mathrm{H}, \mathrm{J}=7 \mathrm{~Hz}), 3.03(\mathrm{t}, 2 \mathrm{H}, \mathrm{J}=7.0 \mathrm{~Hz}), 7.18-7.95(\mathrm{~m}$, $17 \mathrm{H}), 8.30(\mathrm{~m}, 2 \mathrm{H}), 9.20(\mathrm{~s}, 1 \mathrm{H}) .{ }^{13} \mathrm{C} \mathrm{NMR}\left(\mathrm{CDCl}_{3}\right): \delta 20.7$, 29.1, 33.7, 36.7, 48.9, 206.3, 231.3. ${ }^{31} \mathrm{P}$ NMR $\left(\mathrm{CDCl}_{3}\right): \delta 36.8$.

General Procedure for Preparation of 10-14. To a solution of $\mathbf{5}(100 \mathrm{mg}, 0.15 \mathrm{mmol})$ in $5 \mathrm{~mL}$ of $\mathrm{CH}_{2} \mathrm{Cl}_{2}$ was added the corresponding ol efin in excess $(5-10 \mathrm{mmol})$, and the reaction mixture was stirred for $1-3 \mathrm{~h}$. The resulting solution was filtered through silica gel and evaporated to a small volume. The desired complex was precipitated by addition of ether. 
Complex 10. (80\%) IR ( $\mathrm{KBr}): 1630\left(\mathrm{C}=\mathrm{O}\right.$, coordinated). ${ }^{1 \mathrm{H}}$ NMR $\left(\mathrm{CDCl}_{3}\right): \delta 0.93(\mathrm{t}, 3 \mathrm{H}, 50 \%, 7.6 \mathrm{~Hz}), 1.33(\mathrm{~d}, 3 \mathrm{H}, 50 \%$, $7.3 \mathrm{~Hz}), 1.66(\mathrm{~m}, 1 \mathrm{H}, 50 \%), 2.03(\mathrm{~m}, 1 \mathrm{H}, 50 \%), 2.15$ (s, $3 \mathrm{H}$, $50 \%), 2.21$ (s, $3 \mathrm{H}, 50 \%), 2.33(\mathrm{~m}, 1 \mathrm{H}, 50 \%), 2.69(\mathrm{~m}, 1 \mathrm{H}$, $50 \%), 2.97$ (m, $1 \mathrm{H}, 50 \%), 3.17(\mathrm{~m}, 1 \mathrm{H}, 50 \%), 7.29-8.38(\mathrm{~m}$, $19 \mathrm{H}), 9.16(\mathrm{~s}, 1 \mathrm{H}, 50 \%), 9.21(\mathrm{~s}, 1 \mathrm{H}, 50 \%) .{ }^{31} \mathrm{P} N M R$ $\left(\mathrm{CDCl}_{3}\right): \delta 36.3,39.5$. Anal. Calcd for $\mathrm{C}_{30} \mathrm{H}_{29} \mathrm{NOPBF}_{4} \mathrm{Pd}: \mathrm{C}$, 55.9; $\mathrm{H}, 4.54 ; \mathrm{N}, 2.17$. Found: $\mathrm{C}, 56.34 ; \mathrm{H}, 4.53 ; \mathrm{N}, 2.13$. FABMS: $556.2\left(\mathrm{M}^{+}\right)$.

Complex 11. (78\%) IR (KBr): 1708, 1686 ( $\mathrm{C}=\mathrm{O}$, free), 1630 $\left(\mathrm{C}=\mathrm{O}\right.$, coordinated). ${ }^{1} \mathrm{H} N \mathrm{NMR}\left(\mathrm{CDCl}_{3}\right): \delta 2.20(\mathrm{~s}, 3 \mathrm{H}), 2.51$ (s, $1 \mathrm{H}), 2.93(\mathrm{~m}, 2 \mathrm{H}), 3.50(\mathrm{~s}, 3 \mathrm{H}), 7.21-7.67(\mathrm{~m}, 16 \mathrm{H}), 8.04$ $(\mathrm{m}, 1 \mathrm{H}), 8.44(\mathrm{~d}, 2 \mathrm{H}, \mathrm{J}=7.5 \mathrm{~Hz}), 9.29(\mathrm{~s} 1 \mathrm{H}) .{ }^{31} \mathrm{P} N M R$ $\left(\mathrm{CDCl}_{3}\right): \delta$ 37.3. Anal. Calcd for $\mathrm{C}_{31} \mathrm{H}_{29} \mathrm{NO}_{3} \mathrm{PBF}_{4} \mathrm{Pd}$ : C, 54.13; $\mathrm{H}, 4.25$; $\mathrm{N}, 2.03$. Found: $\mathrm{C}, 53.49 ; \mathrm{H}, 4.32 ; \mathrm{N}, 1.89$. FABMS: $600.2\left(\mathrm{M}^{+}\right)$.

Complex 12. (75\%) IR ( $\mathrm{KBr}): 1610\left(\mathrm{C}=\mathrm{O}\right.$, coordinated). ${ }^{1 \mathrm{H}}$ $\mathrm{NMR}\left(\mathrm{CDCl}_{3}\right): \delta 2.28(\mathrm{~s}, 3 \mathrm{H}), 2.95(\mathrm{~d}, 1 \mathrm{H}, \mathrm{J}=2.0 \mathrm{~Hz}), 3.17$ $(\mathrm{s}, 2 \mathrm{H}), 3.46(\mathrm{~m}, 1 \mathrm{H}), 6.69-7.58(\mathrm{~m}, 21 \mathrm{H}), 7.86(\mathrm{~s}, 1 \mathrm{H}), 8.40$ $(\mathrm{s}, 2 \mathrm{H}), 9.11(\mathrm{~s}, 1 \mathrm{H}) \cdot{ }^{13} \mathrm{C} \mathrm{NMR}\left(\mathrm{CDCl}_{3}\right): \delta 27.7\left(\mathrm{COCH}_{3}\right), 44.8$ $\left(\mathrm{CHCH}_{2}\right), 55.8\left(\mathrm{CHCH}_{2}\right), 168.5(\mathrm{C}=\mathrm{N}), 232.5\left(\mathrm{COCH}_{3}\right) .{ }^{31} \mathrm{P}$ NMR $\left(\mathrm{CDCl}_{3}\right): \delta$ 31.2. Anal. Calcd for $\mathrm{C}_{35} \mathrm{H}_{31} \mathrm{NOPBF}_{4} \mathrm{Pd}: \mathrm{C}$, 59.56; H, 4.43; N, 1.98. Found: C, 58.96; H, 4.63; N, 1.79 . FABMS: $618.2\left(\mathrm{M}^{+}\right)$.

Complex 13. (78\%) IR (KBr): $1626\left(\mathrm{C}=\mathrm{O}\right.$, coordinated). ${ }^{1} \mathrm{H}$ $\mathrm{NMR}\left(\mathrm{CDCl}_{3}\right): \delta 0.49(\mathrm{~s}, 1 \mathrm{H}), 1.15(\mathrm{~m}, 2 \mathrm{H}), 1.32(\mathrm{~d}, 1 \mathrm{H}, \mathrm{J}=$ 9.7 Hz), $1.49(\mathrm{~m}, 1 \mathrm{H}), 1.81(\mathrm{~d}, 1 \mathrm{H}$, J $=9.9 \mathrm{~Hz}), 1.91(\mathrm{~m}, 1 \mathrm{H})$, $2.04(\mathrm{~s}, 1 \mathrm{H}), 2.10(\mathrm{~s}, 3 \mathrm{H}), 2.48(\mathrm{~s}, 1 \mathrm{H}), 2.77(\mathrm{~d}, 1 \mathrm{H}, \mathrm{J}=$ $6.5 \mathrm{~Hz}), 7.40-7.93(\mathrm{~m}, 17 \mathrm{H}), 8.40(\mathrm{~m}, 2 \mathrm{H}), 9.19(\mathrm{~s}, 1 \mathrm{H})$. ${ }^{13} \mathrm{C} \mathrm{NMR}\left(\mathrm{CDCl}_{3}\right): \delta 27.0\left(\mathrm{COCH}_{3}\right), 29.3,30.2,36.8,43.1$, 53.5, 71.2, $169.1(\mathrm{C}=\mathrm{N}), 234.7\left(\mathrm{COCH}_{3}\right) .{ }^{31} \mathrm{P} \mathrm{NMR}\left(\mathrm{CDCl}_{3}\right)$ : 35.3. Anal. Calcd for $\mathrm{C}_{34} \mathrm{H}_{33} \mathrm{NOPBF}_{4} \mathrm{Pd}: \mathrm{C}, 58.69 ; \mathrm{H}, 4.78 ; \mathrm{N}$, 2.01. Found: $C, 57.58 ; \mathrm{H}, 4.83 ; \mathrm{N}, 1.89$. FABMS: $608.2\left(\mathrm{M}^{+}\right)$.

Complex 14. (75\%) IR (KBr): $1713(\mathrm{C}=\mathrm{O}$, free), 1610 $\left(\mathrm{C}=\mathrm{O}\right.$, coordinated). ${ }^{1} \mathrm{H} N \mathrm{NMR}\left(\mathrm{CDCl}_{3}\right): \delta 1.92(\mathrm{~s}, 3 \mathrm{H}), 2.12(\mathrm{~s}$, $3 \mathrm{H}), 2.78(\mathrm{~s}, 2 \mathrm{H}), 5.12(\mathrm{~s}, 1 \mathrm{H}), 7.19-7.93(\mathrm{~m}, 17 \mathrm{H}), 8.60$ (s, $2 \mathrm{H}), 9.15(\mathrm{~s}, 1 \mathrm{H}) .{ }^{31} \mathrm{P} \mathrm{NMR}\left(\mathrm{CDCl}_{3}\right)$ : 35.7. Anal. Calcd for $\mathrm{C}_{31} \mathrm{H}_{29} \mathrm{NO}_{3} \mathrm{PBF}_{4} \mathrm{Pd}$ : C, 54.13; $\mathrm{H}, 4.25 ; \mathrm{N}, 2.03$. Found: $\mathrm{C}$, 53.68; $\mathrm{H}, 4.41 ; \mathrm{N}, 1.78$. FABMS: $600.2\left(\mathrm{M}^{+}\right)$.
Complex 15. To a solution of 2 (100 mg, $0.16 \mathrm{mmol}$ ) in $\mathrm{CH}_{2} \mathrm{Cl}_{2}$ was added excess vinyl acetate, and the reaction mixture was refluxed at $80{ }^{\circ} \mathrm{C}$ for about $24 \mathrm{~h}$. The resulting solution was filtered through silica gel, evaporated to a small amount, and precipitated into ether. The pale white sol id was filtered and dried under vacuum ( $75 \mathrm{mg}, 70 \%$ ). IR (KBr): 1620 $\left(\mathrm{C}=\mathrm{O}\right.$, coordinated). ${ }^{1} \mathrm{H}$ NMR $\left(\mathrm{CDCl}_{3}\right): \delta 1.04(\mathrm{t}, 3 \mathrm{H}, \mathrm{J}=7.1$ $\mathrm{Hz}), 1.59(\mathrm{~m}, 2 \mathrm{H}), 2.0(\mathrm{~s}, 3 \mathrm{H}), 5.27(\mathrm{~m}, 1 \mathrm{H}), 7.24-8.10(\mathrm{~m}$, $17 \mathrm{H}), 8.41(\mathrm{~d}, 2 \mathrm{H}$, J $=7.5 \mathrm{~Hz}), 9.3(\mathrm{~s}, 1 \mathrm{H}) .{ }^{31} \mathrm{P} \mathrm{NMR}\left(\mathrm{CDCl}_{3}\right)$ : $\delta$ 34.7. Anal. Calcd for $\mathrm{C}_{30} \mathrm{H}_{29} \mathrm{NO}_{2} \mathrm{PBF}_{4} \mathrm{Pd}$ : C, 54.61; $\mathrm{H}, 4.43$; $\mathrm{N}, 2.12$. Found: C, 54.12; $\mathrm{H}, 4.49 ; \mathrm{N}, 1.91$.

Complex 16. To an autoclave $(100 \mathrm{~mL})$ were loaded the palladium complex 2 (60 mg) in $\mathrm{CH}_{2} \mathrm{Cl}_{2}(10 \mathrm{~mL}), \mathrm{CO}(50 \mathrm{psi})$, and ethylene (50 psi), and the mixture was stirred at room temperature. Reaction stopped after $4 \mathrm{~h}$, and the resulting clear solution was filtered through silica gel and evaporated, which provided a transparent polymeric material (120 mg). ${ }^{1} \mathrm{H}$ NMR $\left(\mathrm{CDCl}_{3}\right)$ : $\delta 1.83(\mathrm{t}, 2 \mathrm{H}), 2.13(\mathrm{~s}, 4 \mathrm{H}), 2.28(\mathrm{~m}, 6 \mathrm{H})$, $2.66(\mathrm{br}, \sim 48 \mathrm{H}), 3.0(\mathrm{t}, 2 \mathrm{H}), 7.24-8.10(\mathrm{~m}, 17 \mathrm{H}), 8.28(\mathrm{~d}, 2$ $\mathrm{H}, \mathrm{J}=6.3 \mathrm{~Hz}), 9.26(\mathrm{~s}, 1 \mathrm{H}) .{ }^{31} \mathrm{P} \mathrm{NMR}\left(\mathrm{CDCl}_{3}\right): \delta 37.7$.

Crystallography. Crystals suitable for X-ray determination were obtained for $\mathbf{1}, \mathbf{2}, \mathbf{3}, \mathbf{4}, \mathbf{7}, \mathbf{1 0}, \mathbf{1 1}$, and 13 by slow diffusion of hexane into a dichloromethane solution at room temperature. Cell parameters were determined by a Siemens SMART CCD or a CAD-4 diffractometer. Selected bond distances and bond angles are collected in Table 2. Other crystallographic data are deposited as Supporting I nformation.

Acknowledgment. We thank the National Science Council for financial support (NSC89-2113-M002-07).

Supporting Information Available: Complete description of the X-ray crystallographic structure determination of $\mathbf{1}, \mathbf{2}, \mathbf{3}, \mathbf{4}, \mathbf{7}, \mathbf{1 0}, \mathbf{1 1}$, and 13 including figures of ORTEP plots and tables of crystal data, atomic coordinates, isotropic and anisotropic thermal parameters, and bond distances and angles. This material is available free of charge via the Internet at http://pubs.acs.org.

OM000880Q 